九州大学学術情報リポジトリ

Kyushu University Institutional Repository

\title{
Utilization of a Tobacco Rattle Virus Vector to Clone a Nicotiana benthamiana cDNA Library for VIGS
}

Seo, Eun-Young

Department of Applied Biology, College of Agriculture and Life Sciences, Chungnam National University

Kim, Hyun-Seung

Department of Applied Biology, College of Agriculture and Life Sciences, Chungnam National University

Kim, Jung-Kyu

Department of Applied Biology, College of Agriculture and Life Sciences, Chungnam National University

Gotoh, Takafumi

Kuju Agricultural Research Center, Faculty of Agriculture, Kyushu University

他

https://doi.org/10.5109/1526392

出版情報：九州大学大学院農学研究院紀要. 60 (2)，pp.331-337，2015-09-18. Faculty of Agriculture, Kyushu University

バージョン :

権利関係 : 


\title{
Utilization of a Tobacco Rattle Virus Vector to Clone a Nicotiana benthamiana cDNA Library for VIGS
}

\section{Eun-Young SEO ${ }^{1}$, Hyun-Seung KIM${ }^{1}$, Jung-Kyu KIM${ }^{1}$, Takafumi GOTOH, John HAMMOND ${ }^{2 *}$ and Hyoun-Sub LIM ${ }^{1 *}$}

\author{
Kuju Agricultural Research Center, Faculty of Agriculture, \\ Kyushu University, Kuju, Oita, 878-0201, Japan \\ (Received May 8, 2015 and accepted May 19, 2015)
}

\begin{abstract}
Virus-induced gene silencing (VIGS) is an efficient and rapid method to identify plant gene functions. One of the most widely used VIGS vectors is Tobacco rattle virus (TRV) which has been used successfully for RNA interference (RNAi) in N. benthamiana and tomato. We previously modified a TRV VIGS vector to contain the Gateway system for high throughput cloning (Ko et al., J. Fac.Agr.,Kyushu Univ., 60(1), 139149 (2015)), and utilized this system to express a library of $N$. benthamiana cDNA. Random c.300 bp N. benthamiana cDNA fragments were generated by ultrasonication and inserted into the TRV VIGS vector by Gateway cloning. N. benthamiana were agroinfiltrated with randomly selected TRV cDNA constructs in Agrobacterium tumefaciens GV 2260. Distinct visible phenotypes were identified in three sets of the inoculated $N$. benthamiana plants. The three distinguished phenotypes showed leaf malformation and necrosis. The three expressed gene inserts were homologous to EST fragments identified as CK290013.1, CK296346.1, and AM8112161.1, and presumably these genes are related to TRV pathogenesis in N. benthamiana. Identification of the selected genes by VIGS will aid further analysis to determine the relationship between VIGS phenotype and gene function.
\end{abstract}

Key words: Tobacco rattle virus, $N$. benthamiana cDNA library, Virus induced gene silencing, Gateway cloning system, Reverse genetics

\section{INTRODUCTION}

Studies of plant genome sequences have been completed through advanced sequencing technologies since the genome sequence of Arabidopsis thaliana was published (Arabidopsis Genome Initiative 2000). Since then, the complete genome sequences of many crop plant species including rice (Yu et al., 2002), maize (Schnable et al., 2009), soybean (Schmutz et al., 2010), chinese cabbage (Brassica rapa Genome Sequencing Project Consortium, 2011), and potato (Potato Genome Sequencing Consortium, 2011) etc., have also been made available.

Although many plant genome sequences are now available, it is often not possible to determine gene function directly from sequence information. Methods to define gene function include overexpression of the gene in transgenic plants, and virus included gene silencing (VIGS) (Burch-Smith et al., 2004). Compared to overexpression in transgenic plants, using VIGS is much more convenient and faster to study gene function. However, VIGS has been limited to testing parts of individual genes or selections from a library. Our previous studies using Alternanthera mosaic virus (Ko et al., 2015) showed that insertion of a whitefly cDNA library to an AltMV VIGS

${ }^{1}$ Department of Applied Biology, College of Agriculture and Life Sciences, Chungnam National University, Daejeon 305-764, Republic Korea

${ }^{2}$ United States Department of Agriculture - Agricultural Research Service, United States National Arboretum, Floral and Nursery Plants Research Unit, Beltsville, MD 20705, USA

${ }^{1 *}$ Corresponding Author (E-mail: hyounlim@cnu.ac.kr)

3* Corresponding Author (E-mail: john.hammond@usda.ars.gov) vector was valuable to screen RNAi for control of Whitefly. At the same time we used a natural isolate of Soybean yellow common mosaic virus to clone a Glycine max cDNA library for future selection of useful soybean genes (Seo et al., 2015). Through this previous research we have established that a viral vector could be utilized directly as the carrier vector to clone plant and insect cDNA libraries to express RNAi, and we have extended these methods to Nicotiana benthamiana.

$N$. benthamiana is extensively used as a model plant in plant biology, and a draft genome sequence is available (Bombarely A et al., 2012). N. benthamiana (family Solanaceae) is native to Australia, and significant expressed sequence tag (EST) data is available in addition to the draft genome (Bombarely et al., 2012). Because this species is an efficient host to a broad range of plant viruses, it has been widely used by plant virologists.

Previously, both $N$. tabacum and $N$. benthamiana have been used for protein expression in transgenic plants, or for transient expression using plant viral vectors. At the same time $N$. benthamiana is a good tool for examining viral cell to cell movement and to support plant cell biology based on fundamental science approaches (Chapman et al., 1992; Cruz et al., 1996; Escobar et al., 2003; Lucas, 2006). VIGS can also be used in $N$. benthamiana as a powerful reverse genetic tool to regulate gene expression to identify or confirm gene function (Dong et al., 2007; Fu et al., 2005; Liu et al., 2002; Ratcliff et al., 2001). Especially, VIGS utilizing the RNA interference (RNAi) mechanisms has been developed with several viral vectors for agro-infiltration, including with $N$. benthamiana which is susceptible to 
multiple plant viruses.

VIGS is an efficient and rapid method to identify plant gene functions through knock down gene expression. One of the most widely used VIGS vectors for application in $N$. benthamiana is Tobacco rattle virus (TRV). Since the development of TRV as a VIGS vector, TRV has been successfully used for RNAi in $N$. benthamiana and tomato (Liu et al., 2002a, 2002b). Experimenting on tomato with VIGS, Liu et al. had introduced the Gateway system to TRV RNA2 as a VIGS vector for fast and easy cloning (Liu et al., 2002b). The modified TRV VIGS vector was used successfully to test tomato EST function. We have previously constructed our own TRV VIGS vector containing the Gateway system for high throughput use in gene function studies, and to better understand TRV interactions with $N$. benthamiana (Macfarlane, 2010).

Because insertion of random $N$. benthamiana cDNA serves to induce RNAi and thus regulate the homologous endogenous target gene, a phenotype different than a wild type TRV infection of $N$. benthamiana is associated with the function of the target of the TRV cDNA insert. In addition, because the TRV vector itself produces very mild symptoms, increased symptom severity induced by the TRV vector expressing RNAi against a random cDNA insert indicates that the target gene may normally confer partial resistance to TRV infection. Therefore, through expression of an $N$. benthamiana cDNA library from the TRV VIGS vector we were able to identify genes related to TRV pathogenesis in $N$. benthamiana.

In related research we have developed Soybean yellow common mosaic virus (SYCMV) as a high throughput soybean gene identification system (Seo et al., 2015), and Alternanthera mosaic virus (AltMV) was also developed for efficient cloning and expression of whitefly cDNA RNAi to screen for gene function (Ko et al., 2015). Each of these VIGS vectors was modified with the Gateway cloning system for easy, efficient construction of large random cDNA libraries.

\section{MATERIALS AND METHODS}

\section{INSERTION OF A GATEWAY CLONING ADAPTER IN THE pTRV MCS}

To generate a Gateway cloning system in the pTRV multiple cloning site (MCS), a Gateway cloning adapter was amplified from pSITE-2CA vector using primers (Table 1) which added recognition sites for restriction enzymes SacI and XhoI, at the 5' and 3' ends, respectively. The PCR product and pTRV vector were each digested with SacI and XhoI and then ligated to generate the pTRV att vector modified with the Gateway cloning system as previously described (Ko et al., 2015).

\section{TOTAL RNA EATRACTION AND mRNA ISOLATION FROM NICOTIANA BENTHAMIANA}

Total RNA was extracted with Trizol reagent (MRC) from leaves of four-week-old $N$. benthamiana and mRNA was isolated with FastTrack ${ }^{\circledR}$ MAG mRNA isolation Kit (invitrogen) as described in the manufacturer's recommended protocol, with mRNA eluted in RNase-free water.

\section{CONSTRUCTION OF AN RNAi CDNA LIBRARY USING THR GATEWAY SYSTEM}

To construct an $N$. benthamiana cDNA library, we followed the methods of our previous studies (Ko et al., 2015, Seo et al., 2015). Isolated mRNA was used for first strand cDNA synthesis using 3' primer Biotin-attB2- $(\mathrm{N})_{25}$ (Table 1), and the RNA digested with RNase I. The first strand cDNA was sonicated for 1 second with a Vcx 750 Watt ultrasonic probe to produce cDNA fragments from 250 bp to 500 bp in size. The double stranded 5' attB1adapter oligomers (Table 1) were ligated to the ends of

Table 1. Oligomers used in this study

\begin{tabular}{|c|c|c|}
\hline Oligomer & Sequence & Feature \\
\hline \multicolumn{3}{|c|}{ Oligomers used in synthesis of cDNA fragments with att site } \\
\hline 5' attB1-adapter & 5'-TCGTCGGGGACAACTTTGTACAAAAAAGTTGG- 3 ' & 5' attB1-adapter \\
\hline Biotine-attB2-(N)25 & 5’-Biotin-GGGGACAACTTTGTACAAGAAAGTTGGG(N)25-3' & Used for first strand synthesis \\
\hline \multicolumn{3}{|c|}{ Oligomers used in amplifying cDNA } \\
\hline 5'attB1-oligo & 5'-TCGTCGGGGACAACTTTGTACAAAAAAGTTGG-3' & 5'-Oligo \\
\hline Biotine-attB2-(N)6 & 5'-Biotin-GGGGACAACTTTGTACAAGAAAGTTGGG(N)6-3' & 3'-Oligo \\
\hline \multicolumn{3}{|c|}{ Oligomers used in sequencing of cDNA library entry clones } \\
\hline pDONR207_F & 5'-TCGCGTTAACGCTAGCATGGATCTC-3' & 5'-Oligo \\
\hline pDONR207_R & 5'-GTAACATCAGAGATTTTGAGACAC-3' & 3'-Oligo \\
\hline \multicolumn{3}{|c|}{ Oligomers used in PCR and sequencing of cDNA library in Agrobacteria } \\
\hline pTRV CP 3' end & 5'-GAT GCT AAC ATC GCG ACT C-3' & 5'-Oligo \\
\hline pTRV att 3' end & 5'-CAT TTG GAT TAC GCT CCA TTT C-3' & 3'-Oligo \\
\hline \multicolumn{3}{|c|}{ Oligomers used in Gateway cloning adapter including restriction enzyme site. } \\
\hline SacI att site F & 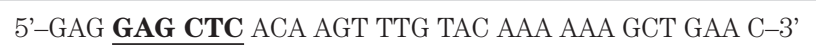 & 5'-Oligo, $\underline{\boldsymbol{S a c I}}$ \\
\hline XhoI att site $\mathrm{R}$ & 5'-GAG CTC GAG ACC ACT TTG TAC AAG AAA GCT G-3' & 3'-Oligo, $\underline{\text { XhoI }}$ \\
\hline
\end{tabular}


the cDNA fragments using T4 DNA ligase, followed by Gateway system cloning. First the cDNA fragments with attached 5' attB1-adapter arms were used for synthesis of second strands using Taq DNA polymerase. The double-stranded DNA fragments with attB1 at 3' ends and attB2 at 5' ends were then amplified by PCR using a mixture of primers 5' attB1 and Biotine-attB2- $(\mathrm{N})_{25}$ (Table 1), in order to generate a large quantity of DNA fragments to construct an RNAi cDNA library.

\section{BP RECOMBINATION}

The attB-flanked amplified cDNA fragments and pDONR 207 vector were used for BP recombination with the BP clonase of the Gateway system. The product of $\mathrm{BP}$ reactions was transformed to One shot ${ }^{\circledR}$ Top10 electrocompetent cells E. coli (Invitrogen). Transformation was performed by electroporator using settings of $1.8 \mathrm{kV}$, $200 \Omega, 25 \mathrm{uF}$ in a final volume of $50 \mu \mathrm{l}$, and then brought to $1 \mathrm{ml}$ with S.O.C. media and incubated in shaking incubator at $37^{\circ} \mathrm{C}$. After an 1 hour incubation, $100 \mu \mathrm{l}$ of the cDNA library was spread on LB plates containing $1 \mu \mathrm{g} / \mathrm{ml}$ gentamycin. To determine the $\mathrm{cDNA}$ library titer, plates were incubated overnight at $37^{\circ} \mathrm{C}$ and colonies counted. Twenty four colonies of $E$. coli were randomly selected from the plate and plasmid isolated to determine redundancy and insert size by PCR amplification and fragment analysis on agarose gel. The isolated plasmids which were used for PCR analysis were also sequenced to confirm diversity of the inserted library fragments. The remaining colonies on the plates were harvested to isolate BP library DNA. Then $300 \mu \mathrm{l}$ aliquots of the remainder of the cDNA library were mixed with an equal volume of sterile $40 \%$ glycerol to create stocks which were stored at $-80^{\circ} \mathrm{C}$.

\section{LR RECOMBINATION}

To generate the TRV att cDNA library, the isolated BP library DNA ( $3 \mu \mathrm{g})$ and modified pTRV att vector were mixed and used for LR recombination (Ko et al., 2015). LR reaction products were transformed to One shot ${ }^{\circledR}$ Top10 electrocompetent cells E. coli (Invitrogen) as above, and plated on LB plates containing $1 \mu \mathrm{g} / \mathrm{ml}$ kanamycin. All of the colonies on the plates were harvested and the resulting purified TRV att cDNA library was transformed into Agrobacterium tumefaciens GV2260 and spread on agar plates containing rifampicin and kanamycin. When Agrobacterium colonies developed, each of the colonies was analyzed by PCR and sequenced using Agrobacteria PCR primers (Table 1) to determine the efficiency of cloning and confirm a low redundancy of the individual constructs (Table 2).

\section{AGRO-INFILTRATION OF NICOTIANA BENTHAMIANA WITH THE TRV att VECTOR CONTAINING RANDOM CDNA INSERTS}

Agrobacterium cultures containing individual TRV att cDNA library clones were each mixed with an equal volume of a culture of Agrobacterium expressing the TRV RNA 1 construct, and agro-infiltrated to 3-4 weekold $N$. benthamiana plants. To prepare the cultures,
Agrobacterium was incubated at $30^{\circ} \mathrm{C}$ for 2 days and resuspended in infiltration buffer (10mM MES, (pH 5.6), $10 \mathrm{mM} \mathrm{MgCl}_{2}$ and $150 \mathrm{mM}$ acetosyringone) at OD600 = 0.6. Equal volumes of the TRV RNA 1 and TRV att RNA 2 cultures were mixed, and $5 \mathrm{ml}$ Agrobacterium suspension was infiltrated on primary leaves of plants in a single pot using a syringe without a needle.

\section{RESULTS AND DISCUSSION}

\section{N. BENTHAMIANA RANDOM CDNA LIBRARY WAS GENERATED USING cDNA SONICATION, PCR AMPLIFICATION AND BP GATEWAY RECOMBINATION}

An $N$. benthamiana random cDNA library was generated by cDNA sonication to get small fragments in the range of 250-500 nt, and these small cDNA fragments then amplified by PCR to add Gateway adapters. The cDNA fragments which were prepared for Gateway cloning were inserted into Gateway donor vector pDONR207 using the $\mathrm{BP}$ reaction enzyme. BP reaction product entry clones were transformed into E. coli and 24 random colonies selected to analyze the inserted cDNA size and sequence. The inserted cDNA size distribution was 200 800 nt (data not shown); the sequences of the selected colonies were analyzed for matches to GenBank gene sequences and EST data. The twenty-four selected colonies all showed distinct sequence insertions; the sequences of eight colonies revealed homologies to $N$. benthamiana or N. tabacum mRNA sequences (Table 2). The remainder of the sequenced colonies were not matched to any EST information. Through the electrophoresis and sequence analysis, inserted cDNA fragments were confirmed to have a suitable size and a low redundancy.

TRANSFER OF THE N. BENTHAMIANA CDNA TO THE TRV att VIGS VECTOR BY GATEWAY LR RECOMBINATION, AND AGROBACTERIUM TRANSFORMATION

Entry clones were isolated from harvested BP cDNA library colonies and the inserts transferred by Gateway LR reaction into the TRV att vector. The LR reaction products were transformed into $E$. coli and then plasmid DNA purified for transformation into Agrobacterium GV2260. Agrobacterium colonies were selected and kept individually to study $N$. benthamiana gene function by the Agro-infiltration method. Hundreds of Agrobacteria colonies were amplified by PCR to sequence the inserted N. benthamiana cDNA. To date the sequences of twentynine clones have been analyzed, as shown in Table 3.

\section{REPRESENTATIVE CLONES OF THE $N$ BENTHAMIANA CDNA LIBRARY WERE AGROINFILTRATION TO PLANTS TO CONFIRM THE UTILITY OF THE TRV att VIGS VECTOR FOR GENE FUNCTION IDENTIFICATION}

Twenty-nine single colonies of the TRV att vector containing $N$. benthamiana cDNA fragments were individually agro-infiltrated to first true leaves of 3-4 week 
Table 2. Identification of $24 \mathrm{BP}$ reaction clones of $N$. benthamiana cDNA library analysed for redundancy and insert sequence against EST data

\begin{tabular}{|c|c|c|c|}
\hline No. & Acc No. & EST data & $\begin{array}{c}\text { Range } \\
\text { (Identities) }\end{array}$ \\
\hline BP 1 & & Unknown & \\
\hline BP 2 & & Unknown & \\
\hline BP 3 & GO603828.1 & $\begin{array}{l}\text { NBERO1CH_T3_042_A06_09JUL2006_048 NBERO1CH Nicotiana benthamiana cDNA, } \\
\text { mRNA sequence }\end{array}$ & $\begin{array}{l}339-589 \\
(89 \%)\end{array}$ \\
\hline BP 4 & & Unknown & \\
\hline BP 5 & CK295035.1 & $\begin{array}{l}\text { EST757749 Nicotiana benthamiana mixed tissue cDNA library, normalized, full-length } \\
\text { Nicotiana benthamiana cDNA clone NBMCR96 5- end, mRNA sequence }\end{array}$ & $\begin{array}{l}128-271 \\
(94 \%)\end{array}$ \\
\hline BP 6 & & Unknown & \\
\hline BP 7 & & Unknown & \\
\hline BP 8 & & Unknown & \\
\hline BP 9 & & Unknown & \\
\hline BP 10 & FG638375.1 & TT-47_L15 Samsun trichome library Nicotiana tabacum cDNA, mRNA sequence & $\begin{array}{c}134-283 \\
(84 \%)\end{array}$ \\
\hline BP 11 & GO603039.1 & $\begin{array}{l}\text { NBERO1CH_T3_033_A05_31JUL2006_047 NBERO1CH Nicotiana benthamiana cDNA, } \\
\text { mRNA sequence }\end{array}$ & $\begin{array}{c}136-312 \\
(89 \%)\end{array}$ \\
\hline BP 12 & & Unknown & \\
\hline BP 13 & CN744195.1 & $\begin{array}{l}\text { SAL_US027xd22r1.ab1 SAL_US N.Bentheme Nicotiana benthamiana cDNA 3-, mRNA } \\
\text { sequence }\end{array}$ & $\begin{array}{l}386-565 \\
(99 \%)\end{array}$ \\
\hline BP 14 & FG195117.1 & $\begin{array}{l}\text { AGN_PNL222df1_c12.trimmed.seq AGN_PNL Nicotiana tabacum cDNA 5-, mRNA } \\
\text { sequence }\end{array}$ & $\begin{array}{l}619-809 \\
(82 \%)\end{array}$ \\
\hline BP 15 & CN745018.1 & $\begin{array}{l}\text { SAL_US007xh21r1.ab1 SAL_US N.Bentheme Nicotiana benthamiana cDNA 3-, mRNA } \\
\text { sequence }\end{array}$ & $\begin{array}{c}179-387 \\
(100 \%)\end{array}$ \\
\hline BP 16 & & Unknown & \\
\hline BP 17 & & Unknown & \\
\hline BP 18 & & Unknown & \\
\hline BP 19 & AM783806.1 & $\begin{array}{l}\text { AM783806 seedling library, SL Nicotiana tabacum cDNA clone nt002154046, mRNA } \\
\text { sequence }\end{array}$ & $\begin{array}{c}114-386 \\
(83 \%)\end{array}$ \\
\hline BP 20 & & Unknown & \\
\hline BP 21 & & Unknown & \\
\hline BP 22 & & Unknown & \\
\hline BP 23 & & Unknown & \\
\hline BP 24 & & Unknown & \\
\hline
\end{tabular}

old $N$. benthamiana seedlings. Individual constructs were inoculated to 3 plants, and a distinctive visible phenotype was observed at about 2 weeks after inoculation (Figure 1). Constructs Agro 29 (CK290013.1), Agro 30 (CK296346.1) and Agro 60 (AM811216.1) induced leaf malformation and necrosis (Figure 1). We have not identified any published reports relating to CK290013.1 (Agro 29) or CK296346.1 (Agro 30) to support our observation of leaf malformation and necrosis. However, AM811216.1 was previously examined in N. tabacum to identify essential genes differentially expressed in leaves (Wolfgang et al., 2008); this EST was extracted from plants after cold treatment to induce genes under oxidative stress. Reactive oxygen species (ROS) caused by plant pathogen or environmental stress induces cell death (Kiselevsky et $a l ., 2014)$. Necrosis of leaves which were inoculated with 
Table 3. Agrobacterium colony PCR and BLAST search data of inserts of TRV VIGS constructs from the N. benthamiana cDNA library

\begin{tabular}{|c|c|c|c|}
\hline No. & Acc No. & EST Data & $\begin{array}{c}\text { Range } \\
\text { (Identities) }\end{array}$ \\
\hline Agro 11 & & Unknown & \\
\hline Agro 15 & & Unknown & \\
\hline Agro 27 & & Unknown & \\
\hline Agro 29 & CK290013.1 & $\begin{array}{l}\text { EST752735 Nicotiana benthamiana mixed tissue cDNA library, normalized, full-length } \\
\text { Nicotiana benthamiana cDNA clone NBMBR88 5' end, mRNA sequence. }\end{array}$ & $\begin{array}{c}578-818 \\
(98 \%)\end{array}$ \\
\hline Agro 30 & CK296346.1 & $\begin{array}{l}\text { EST759060 Nicotiana benthamiana mixed tissue cDNA library, normalized, full-length } \\
\text { Nicotiana benthamiana cDNA clone NBMD115 5' end, mRNA sequence. }\end{array}$ & $\begin{array}{c}444-608 \\
(86 \%)\end{array}$ \\
\hline Agro 31 & & Unknown & \\
\hline Agro 33 & ES886892.1 & $\begin{array}{l}\text { NBT042_2005-09-17_1/NBT042_D04_1 Nicotiana benthamiana trichomes Nicotiana } \\
\text { benthamiana cDNA, mRNA sequence. }\end{array}$ & $\begin{array}{l}1-147 \\
(98 \%)\end{array}$ \\
\hline Agro 39 & GO603828.1 & $\begin{array}{l}\text { NBERO1CH_T3_042_A06_09JUL2006_048 NBERO1CH Nicotiana benthamiana cDNA, } \\
\text { mRNA sequence. }\end{array}$ & $\begin{array}{c}111-391 \\
(91 \%)\end{array}$ \\
\hline Agro 40 & & Unknown & \\
\hline Agro 46 & GO608093.1 & $\begin{array}{l}\text { NBERO1CH_T3_092_A05_15JUL2006_047 NBERO1CH Nicotiana benthamiana cDNA, } \\
\text { mRNA sequence. }\end{array}$ & $\begin{array}{l}77-218 \\
(90 \%)\end{array}$ \\
\hline Agro 47 & & Unknown & \\
\hline Agro 60 & AM811216.1 & $\begin{array}{l}\text { AM811216 COL, cold overnight library Nicotiana tabacum cDNA clone nt006018042, } \\
\text { mRNA sequence. }\end{array}$ & $\begin{array}{c}209-385 \\
(100 \%)\end{array}$ \\
\hline Agro 66 & & Unknown & \\
\hline Agro 70 & & Unknown & \\
\hline Agro 73 & & Unknown & \\
\hline Agro 75 & AM804954.1 & $\begin{array}{l}\text { AM804954 seedling library, SL Nicotiana tabacum cDNA clone nt002307093, mRNA } \\
\text { sequence. }\end{array}$ & $\begin{array}{c}2-202 \\
(100 \%)\end{array}$ \\
\hline Agro 77 & & Unknown & \\
\hline Agro 79 & & Unknown & \\
\hline Agro 83 & & Unknown & \\
\hline Agro 85 & GO606553.1 & $\begin{array}{l}\text { NBERO1CH_T3_074_C06_12JUL2006_044 NBERO1CH Nicotiana benthamiana cDNA, } \\
\text { mRNA sequence. }\end{array}$ & $\begin{array}{l}426-600 \\
(100 \%)\end{array}$ \\
\hline Agro 87 & & Unknown & \\
\hline Agro 93 & & Unknown & \\
\hline Agro 94 & & Unknown & \\
\hline Agro 95 & & Unknown & \\
\hline Agro 96 & & Unknown & \\
\hline Agro 97 & & Unknown & \\
\hline Agro 98 & & Unknown & \\
\hline Agro 99 & & Unknown & \\
\hline Agro 100 & & Unknown & \\
\hline
\end{tabular}


construct No. Agro 60 was therefore presumed to relate to silencing of an oxidative stress response gene. While this construct sequence was identified by a Blast search on nucleotide data, this gene is known to be encoded by the chloroplast genomic DNA of $N$. benthamiana. No. Agro 29 also was also analyzed by Blast search of nucleotide data that identified it as most closely related to the promoter region of the chromomethylase 3 (CMT3) gene of $N$. benthamiana. No. Agro 30 was not matched to any available nucleotide data.

Plant viral vectors may be the most efficient method to obtain initial information about possible gene function of unknown sequences, being far faster than generation of transgenic plants or selection of knockout mutants. A potential disadvantage is that unlike a knockout mutant, VIGS knockdown may be only partial, and may be insufficient to produce a visible phenotype. However, VIGS has a distinct advantage over transgenic plants or knockout mutants, in that expression of genes essential in early development (for which mutants may be lethal, and transgenics or knockouts thus not viable) can be reduced by VIGS in the developed plant.

We have demonstrated through our VIGS research that the genes represented by the constructs Agro 29, 30 , and 60 appear to be strongly related to viral pathogenesis or normal plant development. Further investigation of the selected genes screened by VIGS will be necessary to understand the interactions between TRV and $N$. benthamiana, and how these genes affect the host defenses of $N$. benthamiana against TRV. It is, however, clear from this work that the TRV att VIGS vector has great utility to reveal plant gene function in a high throughput system.

\section{ACKNOWLEDGEMENT}

This research was supported by iPET (Korea Institute of Planning and Evaluation for Technology in Food, Agriculture, Forestry and Fisheries), Ministry of Agriculture, Food and Rural Affairs (Project No. 1120183), Republic of Korea.

\section{REFERENCES}

Bombarely, A., H. G. Rosli, J. Vrebalov, P. Moffett, L. A. Mueller and G. B. Martin 2012 A draft genome sequence of Nicotiana benthamiana to enhance molecular plant-microbe biology research. Mol. Plant Microbe Interact., 25: 1523-1530

Burch-Smith, T. M., J. C. Anderson, G. B. Martin and S. P. DineshKumar 2004 Applications and advantages of virus-induced gene silencing for gene function studies in plants. Plant J., 39: $734-746$

Chapman, S., T. Kavanagh and D. Baulcombe 1992 Potato virus $X$ as a vector for gene expression in plants. Plant J., 2: 549557

Cruz, S. S., S. Chapman, A. G. Roberts, I. M. Roberts, D. A. Prior and K. J. Oparka 1996 Assembly and movement of a plant virus carrying a green fluorescent protein overcoat. Proc. Natl. Acad. Sci. U S A, 93: 6286-6290

Dong, Y., T. M. Burch-Smith, Y. Liu, P. Mamillapalli and S. P. Dinesh-Kumar $2007 \quad$ A ligation-independent cloning tobacco rattle virus vector for high-throughput virus-induced gene silencing identifies roles for NbMADS4-1 and -2 in floral development. Plant Physiol., 145: 1161-1170

Escobar, N. M., S. Haupt, G. Thow, P. Boevink, S. Chapman and K. Oparka 2003 High-throughput viral expression of cDNAgreen fluorescent protein fusions reveals novel subcellular

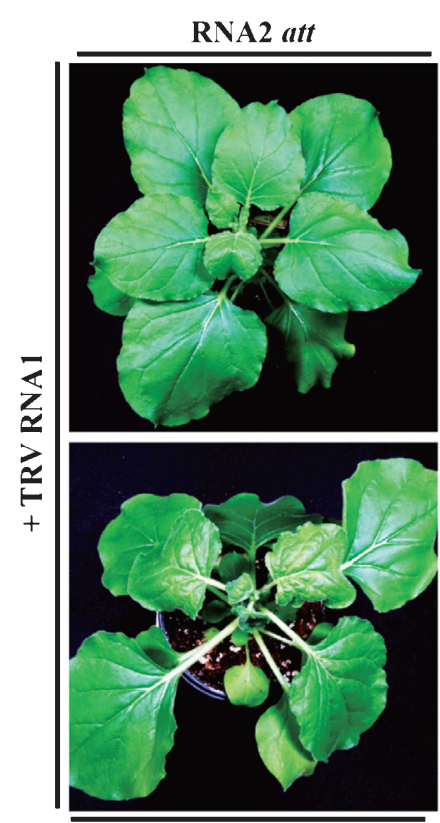

RNA2 att No. Agro 29

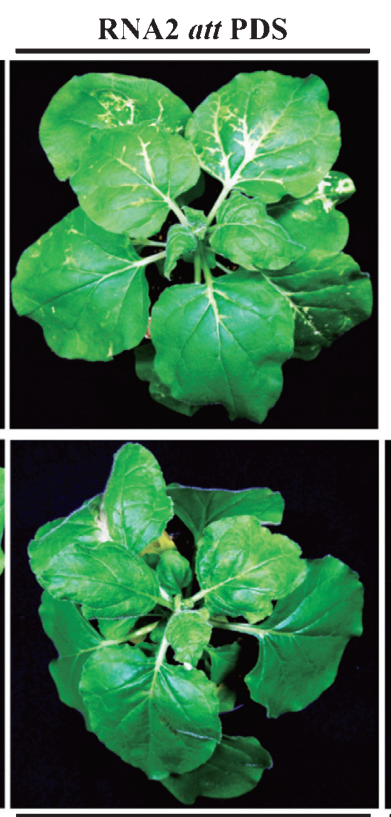

RNA2 att No. Agro 30

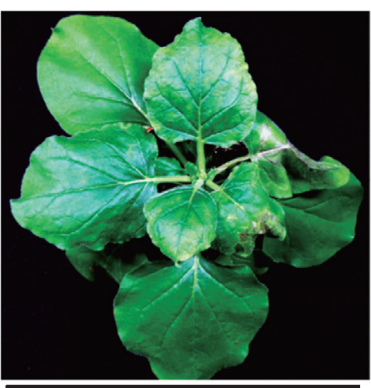

RNA2 att No. Agro 60

Fig. 1. Phenotype of inoculated N. benthamiana producing obvious visible phenotypes caused by TRV induced gene silencing. Plants were infiltrated with TRV att vector, TRV att PDS (phytoene desaturase gene) and TRV att library constructs. N. benthamiana infected with TRV att VIGS Nos. Agro 29, Agro 30, Agro 60 caused necrosis, leaf malformation and growth inhibition. Other plants infected with TRV att VIGS construct had typically viral symptom and leaf malformation but less severe symptoms (picture not shown). 
addresses and identifies unique proteins that interact with plasmodesmata. Plant Cell, 15: 1507-1523

Seo E.-Y., S. Cho, J. S. Moon, T. Gotoh, H. G. Kim, L. L. Domier, S. Lim, K. H. Kim, J.-K. Moon, J. Hammond, H.-S. Lim and K. H. Song 2015 A high throughput soybean gene identification system developed using Soybean yellow common mosaic virus (SYCMV). J. Fac. Agr., Kyushu Univ., 60: 127-138

Fu, D. Q., B. Z. Zhu, H. L. Zhu, W. B. Jiang and Y. B. Luo 2005 Virus-induced gene silencing in tomato fruit. Plant J., 43: 299-308

Kiselevsky, D. B., O. Y. Frolova, A. G. Solovyev, Y. L. Dorokhov, S. Y. Morozov and V. D. Samuilov 2014 Plant cell death caused by fungal, bacterial, and viral elicitors: protective effect of mitochondria-targeted quinones. Biochemistry(Mosc), 79: 1322 1332

Lein, W., B. Usadel, M. Stitt, A. Reindl, T. Ehrhardt, U. Sonnewald and F. Bornke 2008 Large-scale phenotyping of transgenic tobacco plants (Nicotiana tabacum) to identify essential leaf functions. Plant Biotechnol. J., 6: 246-263.

Liu, E., and J. E. Page 2008 Optimized cDNA libraries for virusinduced gene silencing (VIGS) using tobacco rattle virus. Plant Methods, 4: 5

Liu, Y., M. Schiff, R. Marathe and S. P. Dinesh-Kumar 2002a Tobacco Rar1, EDS1 and NPR1/NIM1 like genes are required for N-mediated resistance to tobacco mosaic virus. Plant J., 30: $415-429$

Liu, Y., M. Schiff and S. P. Dinesh-Kumar 2002b Virus-induced gene silencing in tomato. Plant J., 31: 777-786

Lucas, W. J. 2006 Plant viral movement proteins: agents for cellto-cell trafficking of viral genomes. Virology, 344: 169-184

Macfarlane, S. A. 2010 Tobraviruses-plant pathogens and tools for biotechnology. Mol. Plant Pathol., 11: 577-583

Ko N.-Y., H.-S. Kim, J.-K. Kim, S. Cho, E.-Y. Seo, H.-R. Kwon, Y. M. Yu, T. Gotoh, J. Hammond, Y. N. Youn and H.-S. Lim 2015 Developing an Alternanthera mosaic virus vector for efficient cloning of Whitefly cDNA RNAi to screen gene function. J. Fac. Agr., Kyushu Univ., 60: 139-149

Ratcliff, F., A. M. Martin-Hernandez and D. C. Baulcombe 2001 Technical Advance. Tobacco rattle virus as a vector for analysis of gene function by silencing. Plant J., 25: 237-245

Schmutz, J., S. B. Cannon, J. Schlueter, J. Ma, T. Mitros, W. Nelson, D. L. Hyten, Q. Song, J. J. Thelen, J. Cheng, D. Xu, U. Hellsten, G. D. May, Y. Yu, T. Sakurai, T. Umezawa, M. K. Bhattacharyya, D. Sandhu, B. Valliyodan, E. Lindquist, M. Peto, D. Grant, S.
Shu, D. Goodstein, K. Barry, M. Futrell-Griggs, B. Abernathy, J. Du, Z. Tian, L. Zhu, N. Gill, T. Joshi, M. Libault, A Sethuraman, X. C. Zhang, K. Shinozaki, H. T. Nguyen, R. A Wing, P. Cregan, J. Specht, J. Grimwood, D. Rokhsar, G. Stacey, R. C. Shoemaker and S. A. Jackson 2010 Genome sequence of the palaeopolyploid soybean. Nature, 463: 178183

Schnable, P. S., D. Ware, R. S. Fulton, J. C. Stein, F. Wei, S. Pasternak, C. Liang, J. Zhang, L. Fulton, T. A. Graves, P. Minx A. D. Reily, L. Courtney, S. S. Kruchowski, C. Tomlinson, C. Strong, K. Delehaunty, C. Fronick, B. Courtney, S. M. Rock, E. Belter, F. Du, K. Kim, R. M. Abbott, M. Cotton, A. Levy, P. Marchetto, K. Ochoa, S. M. Jackson, B. Gillam, W. Chen, L. Yan, J. Higginbotham, M. Cardenas, J. Waligorski, E. Applebaum, L. Phelps, J. Falcone, K. Kanchi, T. Thane, A. Scimone, N. Thane, J. Henke, T. Wang, J. Ruppert, N. Shah, K. Rotter, J. Hodges, E. Ingenthron, M. Cordes, S. Kohlberg, J. Sgro, B. Delgado, K. Mead, A. Chinwalla, S. Leonard, K. Crouse, K. Collura, D. Kudrna, J. Currie, R. He, A. Angelova, S. Rajasekar, T. Mueller, R. Lomeli, G. Scara, A. Ko, K. Delaney, M. Wissotski, G. Lopez, D. Campos, M. Braidotti, E. Ashley, W. Golser, H. Kim, S. Lee, J. Lin, Z. Dujmic, W. Kim, J. Talag, A Zuccolo, C. Fan, A. Sebastian, M. Kramer, L. Spiegel, L. Nascimento, T. Zutavern, B. Miller, C. Ambroise, S. Muller, W. Spooner, A. Narechania, L. Ren, S. Wei, S. Kumari, B. Faga, M. J. Levy, L. McMahan, P. Van Buren, M. W. Vaughn et al. 2009 The B73 maize genome: complexity, diversity, and dynamics. Science, 326: 1112-1115

Yu, J., S. Hu, J. Wang, G. K. Wong, S. Li, B. Liu, Y. Deng, L. Dai, Y. Zhou, X. Zhang, M. Cao, J. Liu, J. Sun, J. Tang, Y. Chen, X. Huang, W. Lin, C. Ye, W. Tong, L. Cong, J. Geng, Y. Han, L. Li, W. Li, G. Hu, X. Huang, W. Li, J. Li, Z. Liu, L. Li, J. Liu, Q. Qi, J. Liu, L. Li, T. Li, X. Wang, H. Lu, T. Wu, M. Zhu, P. Ni, H. Han, W. Dong, X. Ren, X. Feng, P. Cui, X. Li, H. Wang, X. Xu, W. Zhai, Z. Xu, J. Zhang, S. He, J. Zhang, J. Xu, K. Zhang, X. Zheng, J. Dong, W. Zeng, L. Tao, J. Ye, J. Tan, X. Ren, X. Chen, J. He, D. Liu, W. Tian, C. Tian, H. Xia, Q. Bao, G. Li, H. Gao, T. Cao, J. Wang, W. Zhao, P. Li, W. Chen, X. Wang, Y. Zhang, J. Hu, J. Wang, S. Liu, J. Yang, G. Zhang, Y. Xiong, Z. Li, L. Mao, C. Zhou, Z. Zhu, R. Chen, B. Hao, W. Zheng, S. Chen, W. Guo, G. Li, S. Liu, M. Tao, J. Wang, L. Zhu, L. Yuan and H. Yang 2002 A draft sequence of the rice genome (Oryza sativa L. ssp. indica). Science, 296: 79-92 